\title{
Price regulation of agrarian markets in the context of food security in Ukraine
}

\author{
Olena Shebanina ${ }^{1}$, and Anna Burkovska ${ }^{1, *}$ \\ ${ }^{1}$ Mykolayiv National Agrarian University, Department of Economic Cybernetics and Mathematical Modeling, Mykolayiv, Ukraine
}

\begin{abstract}
The article deals with the problems of price regulation of the agrarian markets in the context of food security in Ukraine. The seasonal dynamics of the indexes on the consumer prices for the agricultural products are analyzed. The influence of the factors of foreign trade activity of Ukraine on the state of prices on the domestic market is determined. The conclusion on the need for increasing the state regulation of prices for agricultural products in Ukraine is made. The analysis of influence of the dynamics in the volumes of the export and import on the fluctuations of prices for agricultural products on the domestic market is carried out.
\end{abstract}

\section{Introduction}

The sharpening of the global food crisis and the formation of negative forecasts for consumers with regard to further price dynamics in the agro-food market will raise the issue of food security for many countries of the world. The problem of ensuring the food security is particularly important for Ukraine, which is predetermined by the current state of the development of the domestic agro-industrial complex. At the same time, favorable natural and climatic conditions for the cultivation of most crops and a strong human potential allow Ukraine not only to provide its own food security, but also to become an active player in the global food market.

Effective agrarian production is the basis for ensuring the country's food security, meeting the needs of the population in a diverse range of food products in sufficient quantity and of high quality. The threats to the food security of Ukraine at the present stage are:

- insufficient consumption of food by the population;

- low consumption of products of animal origin in the energy diet of the population;

- high share of household expenditures on foodstuffs in the structure of their total expenditures;

- high differentiation of the cost of food by social groups;

- low capacity of the domestic market for certain food products;

- import dependence of the country on a separate product;

- raw material export of agricultural products;

- rising prices for agricultural products in the domestic market;

- slow implementation of international standards and food quality systems;

- lack of control over food safety.

\subsection{The relevance and the problem of the research}

\subsubsection{The purpose and objectives of the study}

The economic imbalance in agricultural production, the lack of technical and technological support for agribusiness and the food industry explain the need to study the processes of state price regulation in the food sector. This will stabilize the markets, ensure the security of supply and reasonable prices for the consumer.

The purpose of the study is to form the theoretical foundations of price regulation of agrarian markets in terms of ensuring food security as a component of the economic development of the country. To achieve this goal, the following tasks are necessary:

- study the problems of the price regulation of the agrarian markets in the context of Ukraine's food security;

- analyze the seasonal dynamics of consumer price indexes for agricultural products;

- to determine the influence of factors of foreign trade activity of Ukraine on the state of prices on the domestic market.

\subsubsection{A hypothesis of a scientific problem}

When carrying out agricultural policy it is important to take into account the special nature of agricultural and food production and to understand that the markets for agricultural raw materials and food are two small-scale arrays of the national economy. Agricultural production is generally inelastic depending on prices, if the price fluctuations are of a short-term nature, this sector itself has a conservative character. It is impossible to quickly change the volume of production in cultivation,

\footnotetext{
*Corresponding author: anna.burkovskaya12@gmail.com
} 
horticulture, and viticulture, since it is associated with crop rotation, which limits the maneuvering of sown areas. The effect of factors of intensification (fertilizers, machines, technologies) manifests itself after a certain period and may have ambiguous results depending on the formed natural conditions. Thus, it takes a considerable time to adapt agriculture to a new level of prices, reorientation of the type of activity, subject to changes in prices for means of production in the same direction.

The population, based on their physiological needs, consumes a relatively stable set of food products relatively consistently, while sacrificing expenditures for durable goods in the event of a decline in income. In the formation of demand for cheap food, the Giffen paradox is observed: with the general rise in food prices, consumption of cheap products increases as a result of a sharp decline in demand for more expensive products. On the other hand, in the face of rising incomes or falling prices, there is no adequate growth in demand, as the level of food consumption is determined by two simultaneous factors - physiological and economic, and their actions do not coincide.

The collision in the market of two low-elastic arrays of demand and supply leads to disproportionately large fluctuations in prices. Thus, an increase or decrease in the supply of agricultural products to the market may be accompanied by a change in the prices of food products, which makes the food market, and hence the prices of commodity producers are very volatile. Consequently, the market price mechanism is not able to fully fulfill its main function - to be a regulator of demand and supply, resulting in a food market is not self-regulating, especially in modern mass production and distribution of food. More and more scientists are inclined to believe that the food market, in any case, its main goods, as well as agricultural raw materials, should be regulated, and the main regulator should be the state.

\subsection{Literature Review}

The work of many scholars is devoted to the study of problems of price regulation of agrarian markets. For example, P. Pinstrup-Andersen, F. Cheng [1] and others discussed the issue of food policy development in developing countries. The results of the study of the impact of food price increases on the state of food security are presented in D. Jollife, I. Seff, A. Fuente [2] and others. A thorough study of the indicators of the state of food security in Ukraine with a view to identifying ways to improve was carried out by M. Babych, A. Kovalenko [3] and others. The questions of the impact of customs payments on agricultural food security were covered by J. Beckman, C. Estrades, M. Flores, A. Aguiar [4] and others. The analysis of the impact of the economic availability of food products on food security in the country is highlighted in the writings of O. Shebanina, A. Klyuchnik, A. Burkovskaya, D. Caruso [5], A. Chadwick [6], and others. Models of state support for agri-insurance in the context of global transformation in order to ensure the stability of agrarian markets are presented in works by E. Shkarupa, P. Perehodov, I. Ulanova [7], and others. The role of the information provision of state regulation of the agrarian market was considered by S. Prestamburgo, F. Sgroi [8] and others. The work of D. Debnath, S. Babu, P. Ghosh, M. Helmar [9], S. Mittal, V. Hariharan [10] and others is devoted to the study of the role of state price policy in agrarian markets of countries and regions. The application of macroeconomic models for estimating food losses due to degradation of land resources was considered by P. Panagos, G. Standardi, P. Borrelli [11] and others.

\section{Results and discussion}

Food safety of the country as an integral indicator of the economic and physical availability of food products, as well as their quality, is significantly dependent on the level of solvency of the population, which in turn is derived from the ratio of population growth rates and inflation in the state. High and volatile inflation rates are difficult to quantify, as evidenced by the constant deviation of government forecasts from actual inflation.

In any economic model, the pricing mechanism, which should balance the diversified interests of sellers and consumers of goods, allocate resources, stimulate the rational placement of production, introduction of innovations, etc., occupies a special place. The state and development trends of both separate sectors of the economy and the national economy as a whole depend on the effectiveness of the implementation of this mechanism of the functions entrusted to it. Price dynamics serves as an important indicator of the state of certain sectors of the economy, and the impact on price formation is one of the tools for optimizing economic processes.

The aforesaid is fully concerned with pricing in the domestic agricultural sector. Prices for agricultural products are the most dynamic characteristics of the agrarian market. They react sensitively to the influence of numerous economic, technological, weather, sociopolitical factors, and in turn determine the vectors and pace of development of individual agricultural sectors, the level of food security of the country. Significant differentiation and fluctuations in the dynamics of prices of agricultural products show weak management of processes in the agro-food market. This creates instability, which reduces the investment attractiveness of the agrarian sector, increases the disproportion in the development of its individual components.

In Ukraine, prices for agricultural products, as well as for all other products of domestic producers, tend to grow. This objective phenomenon is associated with inflationary processes in the economy, reflecting the rising cost of almost all resources involved in the national economy. Price volatility has intensified due to the deep economic crisis in Ukraine, which necessitates the continuation of the systematic analysis of the causes and consequences of the processes associated with the formation of prices for agricultural products. The equilibrium market price in this case should be 
considered not as an abstract indicator, but as a ratio of demand and supply.

The fluctuation of prices for agricultural products is seasonal in nature. Consider the seasonal dynamics of agricultural real estate prices indexes in agricultural enterprises in Table 1. The graph of seasonal fluctuations of the price index for the sale of crop production is presented in Figure 1.

Table 1. Seasonal dynamics of price indices in relation to the previous month of sales of crop production by agricultural enterprises.

\begin{tabular}{|c|c|c|c|c|}
\hline \multirow{2}{*}{ Month } & \multicolumn{3}{|c|}{ Annual data of the price index } & $\begin{array}{l}\text { Seasonal } \\
\text { index, } \%\end{array}$ \\
\hline & 2016 & 2017 & 2018 & 102.4 \\
\hline 1 & 101.1 & 104.5 & 103.7 & 102.4 \\
\hline 2 & 109.8 & 103.3 & 102.1 & 104.4 \\
\hline 3 & 101.0 & 103.1 & 103.6 & 101.9 \\
\hline 4 & 102.7 & 102.6 & 105.2 & 102.8 \\
\hline 5 & 101.9 & 97.5 & 98.7 & 98.7 \\
\hline 6 & 97.0 & 98.3 & 95.7 & 96.4 \\
\hline 7 & 101.8 & 98.6 & 98.9 & 99.1 \\
\hline 8 & 92.2 & 95.1 & 97.8 & 94.4 \\
\hline 9 & 94.6 & 97.2 & 99.6 & 96.5 \\
\hline 10 & 101.9 & 104.7 & 98.6 & 101.1 \\
\hline 11 & 102.7 & 101.1 & 101.7 & 101.2 \\
\hline 12 & 101.8 & 103.2 & 100.3 & 101.1 \\
\hline
\end{tabular}

Source: calculated using [12].

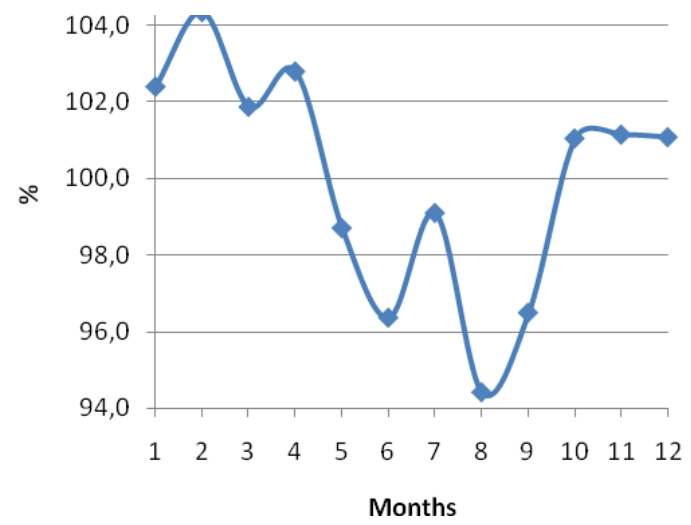

Fig. 1. Distribution of the seasonal wave of fluctuations of the price index of sales of crop production. Source: built using [12].

From the graph it is clear that the period of cheapening of crop production sold by agricultural enterprises is likely for the period from April to September. In other months, prices for plant products show a tendency to increase, which is explained by market conditions.

In the process of economic activity of the enterprise are faced with cyclical fluctuations caused by the seasonal nature of production and consumption of goods and services. Seasonal fluctuations are more or less steady intra-annual fluctuations in a number of dynamics, due to the specifics of production or consumption of one or another species goods or services, therefore the fluctuation of prices for crop production is due to the influence of the following factors:
- lack of capacity of manufacturers to store products, which is why they are forced to sell it at reduced prices in order to avoid damage;

- instability of the market situation, which taken into account the low solvency of the population leads to excess supply and lower prices;

- stochastic nature of the risks of natural disasters, which are reflected in the volumes of offers and prices for agricultural products;

- volatility of the external markets, which leads to fluctuations in prices for export and import contracts and, as a result, fluctuations in the domestic market.

In the conditions of low solvency of the population in the domestic market, producers who are able to produce products of the proper quality at competitive prices, direct their efforts to saturate the external markets. At the same time imported products, which are more competitive than domestic ones, find their consumer in the domestic market of Ukraine.

In turn, price remains the only source for raising the level of profitability and competitiveness of agricultural products, enterprises and industries. Due to the high costs of agricultural production in Ukraine, which does not allow to stabilize market prices in line with the level of solvent demand of the population, there is an urgent need for the state support of agricultural enterprises, aimed at reimbursement of their expenses and stimulation of demand by means of price regulation.

The shift of the vector of exporting and importing operations in agrarian markets is significantly reflected in the pricing policy of producers. Consider the seasonal dynamics of exports of the crop products from Ukraine in Table 2.

Table 2. Seasonal dynamics of export of the crop products

\begin{tabular}{|c|c|c|c|c|}
\hline \multirow{2}{*}{ Month } & \multicolumn{3}{|c|}{$\begin{array}{c}\text { Annual data on export volumes of } \\
\text { vegetable products, USD million }\end{array}$} & $\begin{array}{c}\text { Seasonal } \\
\text { index,\% }\end{array}$ \\
\cline { 2 - 5 } & 2016 & 2017 & 2018 & \\
\hline 1 & 612.7 & 441.6 & 735.7 & 85.0 \\
\hline 2 & 654.0 & 603.5 & 627.5 & 89.5 \\
\hline 3 & 565.3 & 667.6 & 948.6 & 103.5 \\
\hline 4 & 535.4 & 699.5 & 691.0 & 91.4 \\
\hline 5 & 517.7 & 521.9 & 718.5 & 83.5 \\
\hline 6 & 489.0 & 499.2 & 550.1 & 73.0 \\
\hline 7 & 537.3 & 484.9 & 486.9 & 71.6 \\
\hline 8 & 786.6 & 807.2 & 879.9 & 117.4 \\
\hline 9 & 876.6 & 780.4 & 1000.1 & 126.1 \\
\hline 10 & 774.2 & 766.1 & 823.8 & 112.2 \\
\hline 11 & 818.0 & 905.3 & 899.8 & 124.5 \\
\hline 12 & 804.7 & 916.4 & 853.8 & 122.2 \\
\hline
\end{tabular}

Source: calculated using [12].

The graph of seasonal variations in the volumes of exports of the crop products is presented in Figure 2.

It is clear from the graph that the decreasing in the volumes of exports of the crop products is a seasonal characteristic for the period from April to July, at the same time, the volumes of exports of the crop products in the autumn-winter period are the highest, which is due to the conjuncture of foreign markets.

Growing demand for agricultural products on the world market is typical for certain periods and is due to 
the heterogeneity of climatic conditions and consequently the timing of harvesting in the main countries which produce agro-food products.

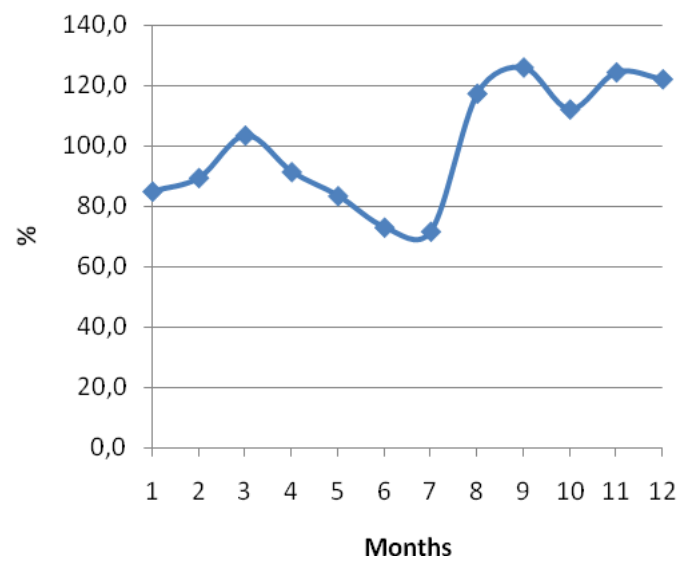

Fig. 2. Distribution of the seasonal fluctuation wave of export volumes of the crop products. Source: built using [12].

Import operations also have an impact on the formation of prices for agricultural products on the domestic market, and fluctuations in volumes of imports of agricultural products are cyclical. Determine the seasonal dynamics of volumes of imports of the crop products in Table 3 .

Table 3. Seasonal dynamics of imports of the crop products

\begin{tabular}{|c|c|c|c|c|}
\hline \multirow{2}{*}{ Month } & \multicolumn{3}{|c|}{$\begin{array}{c}\text { Annual data on import volumes } \\
\text { of vegetable products, USD million }\end{array}$} & $\begin{array}{c}\text { Seasonal } \\
\text { index,\% }\end{array}$ \\
\cline { 2 - 4 } & 2016 & 2017 & 2018 & \\
\hline 1 & 160.8 & 148.5 & 105.7 & 131.1 \\
\hline 2 & 171.2 & 172.9 & 183.3 & 166.6 \\
\hline 3 & 137.2 & 191.2 & 204.3 & 168.3 \\
\hline 4 & 96.4 & 123.5 & 116.9 & 106.4 \\
\hline 5 & 66.0 & 62.0 & 70.3 & 62.6 \\
\hline 6 & 53.8 & 48.8 & 61.9 & 52.0 \\
\hline 7 & 67.5 & 64.4 & 72.5 & 64.6 \\
\hline 8 & 47.4 & 67.9 & 76.1 & 60.5 \\
\hline 9 & 53.4 & 59.5 & 69.6 & 57.6 \\
\hline 10 & 72.1 & 78.5 & 89.2 & 75.7 \\
\hline 11 & 93.8 & 110.9 & 140.8 & 109.1 \\
\hline 12 & 126.6 & 156.7 & 177.5 & 145.6 \\
\hline
\end{tabular}

Source: calculated using [12].

The graph of seasonal variations in volumes of imports of the crop products is presented in Figure 3.

It is clear from the graph that the decreasing in volumes of imports of the crop products is a seasonal characteristic for the period from April to September, when the domestic market is saturated with domestic producers, at the same time, volumes of imports of the crop products in the autumn-winter period are the highest. The conditions of international regional economic integration actualize for Ukraine the task of efficient use of the domestic market as an instrument for strengthening the competitiveness of the national economy and guaranteeing food security. In this context, the development of a competitive environment in the domestic market on the basis of balancing the positions and interests of producers and importers, as well as minimizing the shadow content of domestic commodity markets, should become an important part of the modern strategy of the food independence.

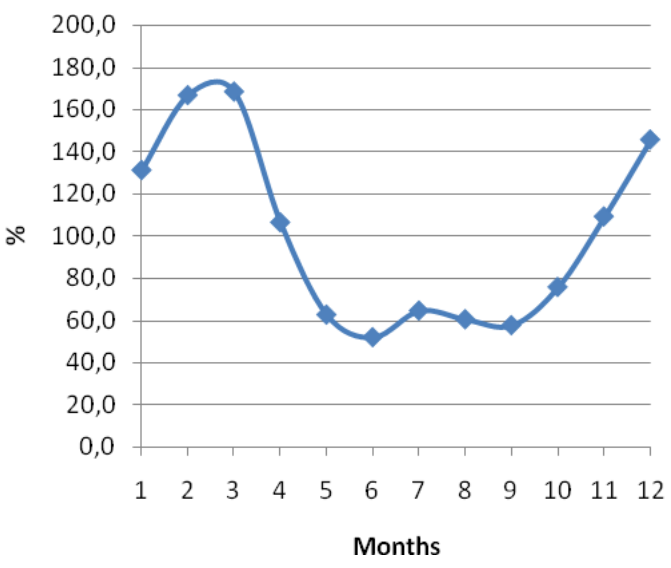

Fig. 3. Distribution of the seasonal fluctuation wave of import volumes of the crop products. Source: built using [12].

The role of foreign trade relations of the country is growing in the conditions of intensification of the globalization processes of the world economy. The international trade as a form of international economic relations forms part of a balanced economic development, promotes the competitiveness of the national economy, increases the standard of living of the population and provides the most complete satisfaction of its needs. The external sector of any country is experiencing economic pressure not only from other partner countries and competitors in world markets, but also from its own internal market and its infrastructure.

The organization of the civilized market of products of the agrarian sector is impossible without the active regulatory role of the state. One of the important tasks is the application in the process of carrying out functions of the state management of the balance method of market regulation, which allows to find out the important tendencies of development of its separate segments, to identify the risks of providing consumers with the agricultural raw materials, and the population - with the food products. The preparation of forecast balances for matching demand and supply for their optimization, as well as reporting balances on production and use of products, balancing control over the matching of supply demand allows predicting differences between them and timely application of effective mechanisms of the state regulatory influence.

Influence of dynamics of seasonal changes in volumes of export and import on seasonal fluctuations of the price index of sales of crop production of domestic production is noticeable. Let's consider the mutual arrangement of the distribution curves of seasonal variations of the studied indicators in Figure 4.

Consequently, from Figure 4 it can be concluded that the seasonal changes in the volumes of export and import of crop production are synonymous with the seasonal fluctuations of the prices of crop production prices. In the periods when there is a decrease in exports due to changes in the external markets, the reduction in 
prices for the exported products is noticeable. The growth of export supplies leads to a gradual increase in prices on the domestic market. Increasing the volumes of imported supplies to the domestic market of Ukraine is inherent only for those months when high prices for products of national producers are established, which is related to the conditions of cultivation and storage of the agricultural products.

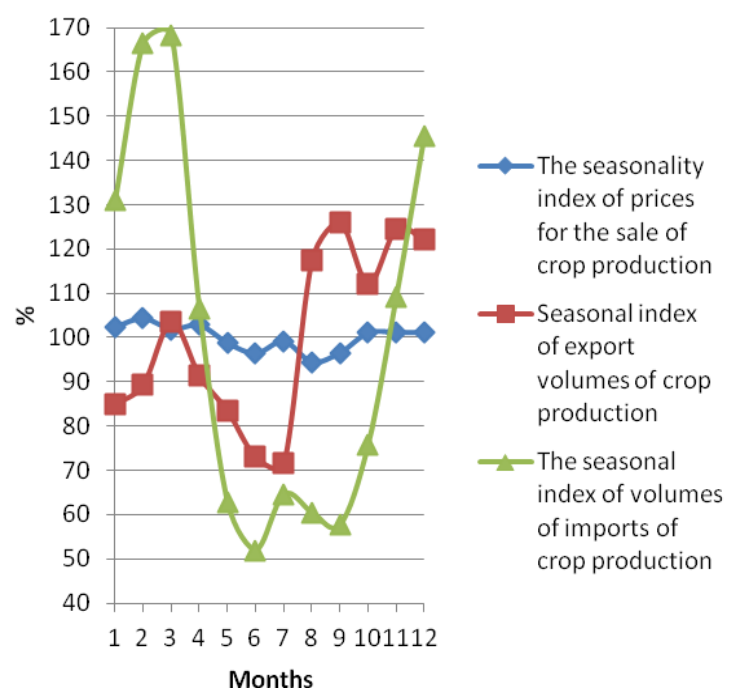

Fig. 4. Distribution of seasonal waves of the index of prices for the sale of crop production, as well as volumes of export and import of crop production. Source: built using [12].

\subsection{Prospects of the situation}

Obviously, it will not be possible to completely avoid significant fluctuations in the dynamics of prices for agricultural products. However, the tools to mitigate the negative effects of these fluctuations are well known. This is about insurance of risks, including during exchange trading, development of integration links between agricultural producers and processing enterprises. The activity of the Agrarian Fund of Ukraine is aimed at smoothing the price fluctuations.

The Resolution of the Cabinet of Ministers of Ukraine "On the Agrarian Fund" No. 543 stipulates that since 2005 the Agrarian Fund has been established and is operating in Ukraine. The Agrarian Fund is a state specialized budget institution authorized to implement price policy in the agro-industrial complex of Ukraine. At the same time, the main task of the Agrarian Fund of Ukraine from the standpoint of ensuring food security is the formation of the state intervention fund by the objects of state price regulation exclusively for the implementation of commodity and financial interventions in the organized agricultural market.

Commodity interventions are carried out by the Agrarian Fund through the sale of certain objects of state price regulation in the organized agricultural market on the spot or on the forwards in order to establish the price of the equilibrium at a rate not exceeding the value of the maximum intervention price. Financial interventions include the purchase of agricultural products at the fall of spot prices in the organized agricultural market below the minimum level, which is carried out in order to achieve a level of equilibrium, including through the acquisition of commodity derivatives. Thus, the Agrarian Fund provides the price regulation objects to the state intervention fund through the procurement of funds from the special fund of the state budget. In case of the increasing in market prices, the Agrarian Fund, due to the established reserves of state price regulation objects, carries out the commodity interventions.

\subsection{Recommendations}

The dynamics and fluctuations of prices for agricultural products is a factor that significantly affects the behavior of its producers, creating trends in the agrarian sector of the economy. Adaptation to the negative effects of this factor occurs mainly in the form of redistribution of resources in favor of certain agricultural sectors; increases the level of concentration of production by eliminating from the market of small business entities. As a consequence, the role of agricultural producers in the process of forming prices for their products is increasing.

First of all, the price regulation of the agrarian markets should take place on the basis of forecasting of the seasonal fluctuations of prices for the agricultural products. Ensuring the effectiveness of the domestic market and the price regulation is a priority direction of the agrarian sector in the context of ensuring food security in Ukraine, which allows to provide the basis for the stable development of agrarian production, to increase its competitiveness, to overcome price imbalances, to strengthen state support of commodity producers using the achievements of European experience.

Improving the pricing process should provide the formation of identical and transparent conditions for the implementation to all agricultural enterprises. Equally important task is to make the agricultural commodity prices more predictable in the dynamics, thus avoiding the losses associated with the disorientation of the agricultural producers due to their noticeable fluctuations. The experience of the previous years shows that it is not necessary to put the excessive expectations on the regulation by the state authorities of the pricing process by the administrative methods. Certainly, the state control in this area is absolutely necessary, but its implementation should also ensure the compliance with the principles of the fair economic competition.

Improving the pricing process involves the creation of the favorable conditions for the development of the entrepreneurial activity, which will allow to increase the number of partners of the agricultural enterprises involved in the process of selling their products. It is about the development of an intermediary institution, the deployment of sales or multi-functional service cooperatives, wholesale markets and other elements of market infrastructure. Competition between the intermediaries, the availability of agricultural enterprises to choose a profitable channel of product sales, and the 
elimination of the negative effects of monopsony in its sales system will enable the creation of the market environment in which there will be no apparent distortion in the pricing process in favor of one of the parties. In connection with the increasing influence of the factors of the growth of prices for the agricultural products, it is necessary to develop the infrastructure and increase the competitiveness of the market, which will prevent unjustified increasing of prices, abusing unfair methods of competition, reduce unproductive and overhead costs of producers.

\section{Conclusions}

The state is the main subject of national food security. In carrying out this function, it precedes from the fact that sufficient security of a person and society is impossible without effective protection of the state interests. The practice of democratic states clearly indicates that the degree of protection of the individual and society is directly dependent on the level of security of the state. Therefore, ensuring food security is a basic among the main functions of state regulation of agriculture.

Particularly important functions of the state administration in agriculture economy of Ukraine are creation of such conditions, which will not only stimulate each producer to respond to consumer inquiries, but also force them to adapt to solvent demand, regulate volumes of production structure in a timely manner and improve the consumer properties of food products. Achievement of this goal should promote the reform of the price mechanism in agriculture. Prices should reflect the level of public utility of the product, interact with the system of non-price levers of state support for agriculture.

World practice has accumulated considerable positive experience in developing mechanisms for equalizing the negative effects of the natural agrarian market. The most widespread is the substantiation and legislative implementation of the upper and lower bounds of prices supported by the financial and commodity interventional activities of the state, the creation of a food fund to safeguard the domestic market from shortages of supply in poor harvest years, and protect producers and consumers from the speculative actions of the intermediaries, state control over dumping practices monopoly traders on the market, a ban on monopoly companies from renting agricultural crops to grow their own raw materials, the implementation of a balanced customs policy, etc.

\section{References}

1. Pinstrup-Andersen, P., Cheng, F. (ed.): Case Studies in Food Policy for Developing Countries. Cornell University Press, New York (2009)

2. Jollife, D., Seff, I., Fuente, A.: Food Insecurity and Rising Food Prices: What Do We Learn from Experiential Measures. World Bank Policy Research Working Paper. https://ssrn.com/abstract=3178465 (2018). Accessed 1 April 2019
3. Babych, M., Kovalenko, A.: Food Security Indicators in Ukraine: Current State and Trends of Development. Baltic Journal of Economic Studies. 4, 8-15 (2018). doi:10.30525/2256-0742/2018-4-18-15.

4. Beckman, J., Estrades, C., Flores, M., Aguiar, A.: The Impacts of Export Taxes on Agricultural Trade. NBER (2018). doi:10.3386/w24894

5. Shebanina, O., Klyuchnik, A., Burkovska, A., Caruso, D.: Providing Labour Income as a Supporting Factor of the Food Security. Management Theory and Studies for Rural Business and Infrastructure Development. 40, 597-608 (2018). doi:10.15544/mts.2018.52

6. Chadwick, A.: Gambling on Hunger? The Right to Adequate Food and Commodity Derivatives Trading. Human Rights Law Review. 2, 233-265 (2018). doi:10.1093/hrlr/ngy008

7. Shkarupa, E., Perehodov, P., Ulanova, I.: Regional State-Supported Agricultural Insurance Development in Context of Global Transformations. AEBMR. 39, 573-577 (2018). doi:10.2991/cssdre18.2018 .118

8. Prestamburgo, S., Sgroi, F.: Agro-food Markets' Functional Efficiency, Products' Quality and Information's Role. Quality: Access to Success. 19, 145-149 (2018)

9. Debnath, D., Babu, S., Ghosh, P., Helmar, M.: The impact of India's food security policy on domestic and international rice market. Journal of Police Modeling. 40, 265-283 (2018). doi:10.1016/j.jpolmod.2017.08.006

10. Mittal, S., Hariharan, V., Subash, S.: Price volatility trends and price transmission for major staples in India. Agricultural Economics Research Review. 31, 65-74 (2018). doi:10.5958/09740279.2018.00006.X

11. Panagos, P., Standardi, G., Borelli, P., Lugato, E., Montanarella, L., Bosello, F.: Cost of Agricultural Productivity Loss Due to Soil Erosion in the European Union: From Direct Cost Evaluation Approaches to the Use of Macroeconomic Models. Land Degradation \& Development (2018). doi:10.1002/1dr.2879

12. State Statistics Service of Ukraine. http://www.ukrstat.gov.ua (2019). Accessed 22 Mar 2019 